\title{
Effects of land use on streams: traditional and functional analyses of benthic diatoms
}

\author{
Csilla Stenger-Kovács (1) Edina Lengyel · Viktor Sebestyén · Beáta Szabó
}

Received: 26 March 2020/Revised: 3 May 2020/ Accepted: 7 May 2020/Published online: 15 May 2020

(C) The Author(s) 2020

\begin{abstract}
Agriculture and urbanisation, the two forms of land use, represent serious threats to the ecological status of aquatic ecosystems, especially in the case of small streams at low altitudes. In this study, 75 Hungarian streams were analysed to explore the effects of these land use types on the composition of benthic diatom communities and their richness. In the Carpathian region, species and trait composition, as well as species richness, varied primarily according to the local environmental variables followed by the shared effects of the environmental factors and land use types. At the same time, functional richness was chiefly explained by the pure effects of land use. However, the difference in trait composition between
\end{abstract}

Handling editor: Judit Padisák

Electronic supplementary material The online version of this article (https://doi.org/10.1007/s10750-020-04294-y) contains supplementary material, which is available to authorized users.

C. Stenger-Kovács $(\bowtie) \cdot$ E. Lengyel

Department of Limnology, University of Pannonia,

Egyetem u. 10, Veszprém 8200, Hungary

e-mail: stenger@almos.uni-pannon.hu

V. Sebestyén

Department of Environmental Engineering, University of Pannonia, Egyetem u. 10, Veszprém 8200, Hungary

B. Szabó

Centre for Ecological Research, Balaton Limnological Institute, Klebelsberg Kuno u. 3, Tihany 8237, Hungary areas dominated by forest (low profile guild, small cell size) and agriculture (motile ecological guilds with middle size, linear-lanceolate shape) was obvious. Higher proportion of water and artificial surfaces might support the spread of diatom species with specific traits: low profile guild with a slightly elongated outline. Nevertheless, no effect of urbanisation on the set of traits, species composition and richness was detected at either local or catchment scale, which might be due to the relatively small portion of artificial surfaces in the watersheds as a whole.

Keywords Diatoms - Traits - Richness - Catchment properties

\section{Introduction}

Most of the world's ecosystems are threatened in some degree by anthropogenic disturbance and climate change leading to a rapid, continuous decline in the Earth's biodiversity (e.g. Butchart et al., 2010) and a previously unprecedented rate of species extinction (Barnosky et al., 2011). Rivers and streams are most affected by these disturbances (Dudgeon et al., 2006). This situation gives rise to an urgent need to understand and predict the consequences of anthropogenic disturbance of ecosystems, which has guided recent 
scientific trends. The NAWQA [National Water Quality Assessment program] (1991-) in the USA, SASS (South Africa Scoring System, 1992-) in South Africa and WFD (Water Framework Directive, 2000-) in the European Union have already been supporting a number of research projects which focus on the factors determining ecological status of surfaces waters.

On regional scale (i.e. on the catchment basins and ecoregion levels), climate, geology, hydrogeology and anthropogenic activities collectively influence the local variables of streams (e.g. current velocity, water temperature and chemical parameters) (Stevenson et al., 1996). Among the numerous anthropogenic pressures, agricultural land use and urbanisation (Allan, 2004) represent serious and cumulative threats to the dynamics and status of aquatic ecosystems worldwide (Richards et al., 1996; Grimm et al., 2008), especially in the reduction of diversity (Li et al., 2020). Catchment basins are degraded by the conversion of forests and natural pasture lands to agricultural uses, with the concomitant intensive application of pesticides, herbicides and fertilizers, moreover, the regulation of streams, rivers and the drainage of wetlands causing water pollution, stream bed erosion, reductions in water quality and quantity and other environmental and ecological problems (Hoorman et al., 2008). High population density, inputs from industrial and domestic sewage and a modified riparian zone of streams are all characteristic of urban areas (Docile et al., 2016), which can lead to the loss of diversity and the homogenisation of aquatic communities (Barnum et al., 2017). The global increase in urban settlements (Seto et al., 2011) has resulted in a significant rise in the extent of the area covered by impermeable surfaces (e.g. roads, roofs, parking places) (Walsh et al., 2004) in many catchment areas. The presence of such surfaces accelerates runoff and, consequently, modifies the hydrological cycle (Sterling et al., 2012). Furthermore, increasingly unpredictable storms and extreme weather events make it easier for toxic substances and nutrients to reach surface waters (Wang et al., 1997).

Rivers at lower altitudes with relatively longer residence times are even more exposed to the effects of intensive land use (Stoate et al., 2001). Small streams with relatively large catchment areas are disproportionately affected by human activity making them more vulnerable, as their small volume does not allow the effective dilution of the various pollutants (Borics et al., 2016). For these reasons, the analysis of such catchments is a matter of urgency for researchers $(\mathrm{Qu}$ et al., 2018).

Aquatic organisms (fish, macroinvertebrates, diatoms; e.g. Hering et al., 2006) indicate quite well the characteristics and degradation level of the catchment area (Walsh \& Wepener, 2009). Diatoms are especially good indicators of catchment land use (Dahm et al., 2013), and can serve as a proxy of the degree of eutrophication (Bellinger et al., 2006), urbanisation (Newall \& Walsh, 2005) and inorganic pollution (Dela-Cruz et al., 2006). A number of studies have examined the effect of land use on different organisms, such as fishes (e.g. Wang et al., 1997; Tóth et al., 2019), macroinvertebrates (Sponseller et al., 2001; Jonsson et al., 2017) and diatoms (e.g. Leland, 1995; Walsh \& Wepener, 2009; Teittinen et al., 2015; Oeding et al., 2018), considering their integrated or separated responses. Some of the comparative studies (Dahm et al., 2013; Tolkkinen et al., 2016) revealed the greater sensitivity and stronger response of diatom communities (Mangadze et al., 2016). However, these earlier diatomological studies focused on the traditional, species-based community analyses, and in spite of their great number, the understanding of the complex effect of land use on lotic ecosystems and ecological processes remained a major challenge (Pan et al., 2004; Allan, 2004). The development and test of different ecological approaches may serve as a basis for collecting knowledge about freshwater ecosystems in order to protect, manage or restore them (Vörösmarty et al., 2010.)

The functional, trait-based approach may also represent a new way of revealing these processes, as it possesses many advantages: easier and faster identification of the different traits, and its use is irrespective of ecoregions, thereby offering a more robust, ecological meaningful knowledge (e.g. Dolédec \& Statzner, 2008; Flynn et al., 2011) as opposed to species-based methods. The functional approach uses different, ecologically important traits of several species to provide a more accurate prediction of ecosystem function and enhance the proportion of variance in a community explained by environmental variables (Abonyi et al., 2018; Stenger-Kovács et al., 2020). In recent years, more studies have dealt with the effect of land use from a functional perspective, as it is reported for macroinvertebrates (Barnum et al., 2017) and phytoplankton (Qu et al., 2018), where there is a 
longer tradition of this approach (e.g. Wallace \& Webster, 1996; Reynolds et al., 2002) when compared to diatoms (e.g. Berthon et al., 2011; Novais et al., 2014).

The main goal of the present study was to examine the effects of the catchment scale land use forms and related environmental variables on the diatom species and trait composition. Furthermore, we aimed to determine their relative contribution (pure and shared effects) to the explained variation in community structure regarding both species and trait composition, as well as in species and functional richness. In further analyses, we specified the relationships between land use types and traits, and land use types and richness. Beside the catchment scale effect of urbanisation, we also highlighted its local effects; therefore, we compared the benthic diatom communities, species and functional richness within, below and far away from the urban sites.

We hypothesized that there is a strong relationship between the environmental variables and the land use forms, and they firmly determine the diatom communities at catchment scale, resulting in a high proportion of community variance explained by them. We assumed that the variation in species and trait composition, as well as in species and functional richness, is mostly associated to the shared effect of the environmental and catchment variables. Furthermore, more diatom traits should be identified as appropriate indicators of the land use forms similar to functional and species richness. We presume that the local effect of urbanisation is more pronounced than its catchment scale effect due to the pollutants concentrated in urban sites.

\section{Materials and methods}

Sampling sites and land use properties

The sampling sites were selected according to their position in the catchment. We regarded a site as ideal if it was located at the end of a downstream section within the catchment basin. Consequently, all of the anthropogenic effects present in the whole catchment basin were combined and represented at the given sampling site (Fig. 1). The initial database contained data from different projects: (i) the Ecosurv project (226 stream sites); and (ii) research projects

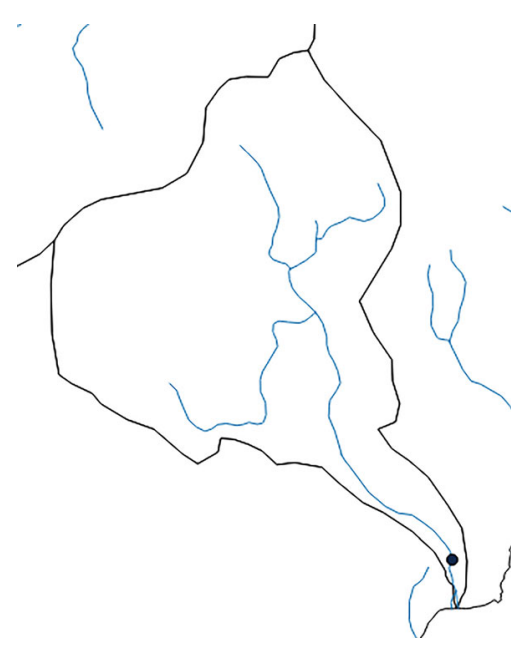

Fig. 1 Ideal sampling point on the stream and its catchment area (sampling site on Örvényesi-séd in 2010)

undertaken by the University of Pannonia (46 stream sites in 2004 and 64 in 2010) (Stenger-Kovács et al., 2014). In the database of 334 stream sites, a total of 75 sites met the criterion detailed above, and were therefore eligible for our further analyses (Fig. 2, Appendix 1-Supplementary Material). A vectorbased digital map of Hungarian stream segments and their corresponding catchments were used in this study. Individual land use types and their extent in a given catchment basin were determined with Quantum GIS software (version 2.18.3) based on 2006 (for samples from 2004 and 2005) and 2012 (for samples from 2010) Corine digital maps (1:100,000) ("Copernicus 2020"). The smallest cartographic unit was $25 \mathrm{ha}$, and the geometrical accuracy was $<100 \mathrm{~m}$. Five different land use categories were employed: (1) artificial surfaces, (2) agricultural areas, (3) forest and seminatural areas, (4) wetlands and (5) water bodies.

Species- and trait-based diatomological analyses

Phytobenthos samples were oxygenized employing the hot hydrogen peroxide method (CEN, 2003). One drop of the treated and homogenised diatom sample was then embedded in synthetic resin. The preparation was examined using a light microscope $(x 1000$ magnification) and counting at least 400 diatom valves. Species identification was based on the current (at the time of sample processing) taxonomic guides. However, recent nomenclature was subsequently checked and updated, allowing the correction of the 


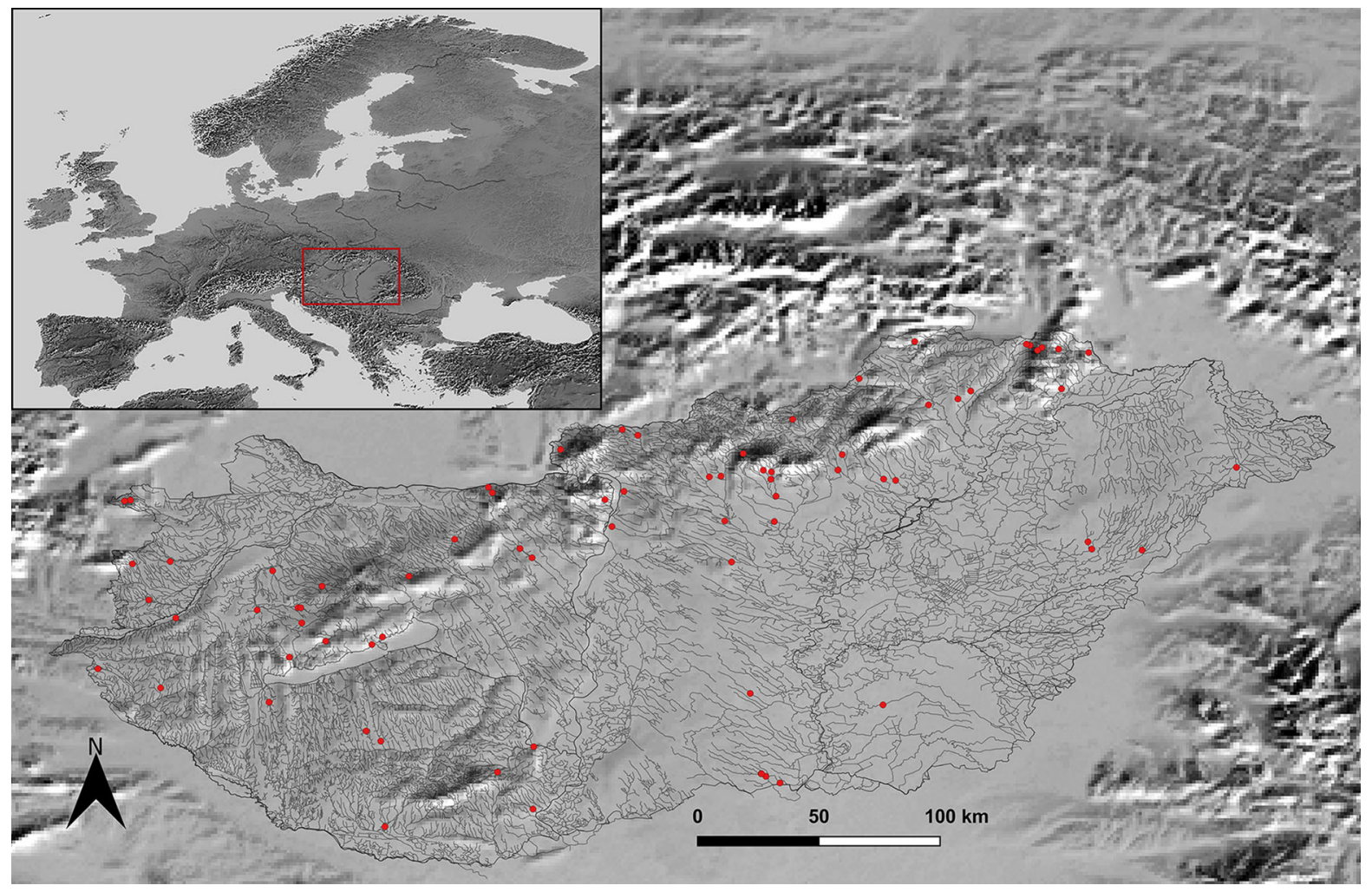

Fig. 2 The 75 stream sites in the Carpathian basin

taxonomic position of the various species (Algabase, 10 November 2019; Guiry \& Guiry, 2019). In the next step, the types of the traits to be employed in the study were determined. These consisted of four diatom ecological guilds (four ecological categories, Passy, 2007; Rimet \& Bouchez, 2012), cell size (five morphological categories; Rimet \& Bouchez, 2012), length-width cell ratio (six morphological categories; Tapolczai et al., 2017) and their combination, known as ecomorphological groups (48 categories, Béres et al., 2016) (Table 1).

Water chemical analyses

The $\mathrm{pH}$ and conductivity were measured in the field and $1.5 \mathrm{~L}$ water was collected and kept in darkness at $7^{\circ} \mathrm{C}$ for further laboratory analyses. The concentrations of ammonium, nitrite, nitrate, chloride, sulphate, TP (Total Phosphorus), SRSi (Soluble Reactive Silica), $\mathrm{HCO}_{3}{ }^{2-}$ were determined following international standards (APHA, 1998; Wetzel \& Likens,
2000). Dissolved inorganic nitrogen (DIN) was calculated as the sum of $\mathrm{NO}_{3}{ }^{-}-\mathrm{N}, \mathrm{NO}_{2}{ }^{-}-\mathrm{N}$, and $\mathrm{NH}_{4}{ }^{+}-\mathrm{N}$.

Statistical analyses

Principal component analysis (PCA) was run to reveal patterns of local environmental variables measured at the sampling sites and different land use forms characteristic of the catchment basins. Redundancy analyses were applied to evaluate the effect of the environmental variables and land use types on the diatom species $\left(\mathrm{RDA}_{1}\right)$ and trait composition $\left(\mathrm{RDA}_{2}\right)$. Linear models were constructed to clarify the relationship between the traits and the land use forms, as well as between the species and functional richness and land use types. Functional richness (FRic) is the major component of functional diversity defined as the amount of functional niche space occupied by the species within a community (Villéger et al., 2008). Variance partitioning (Borcard et al., 1992) was run to quantify the pure and shared effects of the environmental variables and the land use forms on the species- 
Table 1 The applied trait categories in the Hungarian small streams at low $(<350 \mathrm{~m})$ altitudes

\begin{tabular}{ll}
\hline Applied traits & High profile ecological guild (H) \\
& Low profile ecological guild (L) \\
& Motile ecological guild (M) \\
& Planktic guild (P) \\
Cell biovolume (S) & $\mathrm{S} 1<100 \mu \mathrm{m}^{3}$ \\
& $100 \mu \mathrm{m}^{3} \leq \mathrm{S} 2<300 \mu \mathrm{m}^{3}$ \\
& $300 \mu \mathrm{m}^{3} \leq \mathrm{S} 3<600 \mu \mathrm{m}^{3}$ \\
& $600 \mu \mathrm{m}^{3} \leq \mathrm{S} 4<1500 \mu \mathrm{m}^{3}$ \\
& $\mathrm{~S} 5 \leq 1500 \mu \mathrm{m}^{3}$ \\
& $\mathrm{LW} 1<2$ \\
& $2 \leq \mathrm{LW} 2<4$ \\
& $4 \leq \mathrm{LW} 3<6$ \\
& $6 \leq \mathrm{LW} 4<12$ \\
& $12 \leq \mathrm{LW} 5<20$ \\
& $\mathrm{LW} 6 \geq 20$
\end{tabular}

based and trait-based composition of the communities (VarPart 1 , VarPart 2 ), moreover, on the species and functional richness (VarPart 3 , VarPart 4 ). Prior to the variance partitioning, the most important environmental variables and land use forms $(p<0.05)$ in relation to the species- and the trait-based community structures were selected using ANOVA of RDA models with forward selection method. In the case of the species and functional richness, the most decisive variables were selected according to the Akaike information criterion using forward method to develop a linear model with smallest AIC value. In each case, the selection procedures were conducted on the two explanatory data matrices (environmental variables and land use forms) separately. Significance level of the testable fractions (the pure fractions) was determined applying ANOVA in the case of VarPart ${ }_{1}$, VarPart $_{2}$. The non-metric multidimensional scaling (NMDS) method was used to examine the local effect of urbanisation (towns and villages) on the species and trait composition $\left(\mathrm{NMDS}_{1}\right.$ and $\mathrm{NMDS}_{2}$ ): if the sampling was conducted (i) actually in the town, (ii) below the town, up to $1 \mathrm{~km}$ downstream, or (iii) far away (more than $1 \mathrm{~km}$ ) from the urban area. Calculations were based on the distance matrix of communities, applying the Bray-Curtis index. ANOSIM with Bray-Curtis index was performed to test whether diatom communities differ significantly according to their closeness to an urban area. Furthermore, Kruskal-Wallis test was performed to show any differences or similarities in species and functional richness at these three site types.

Prior to the analyses, the environmental data were transformed (conductivity, SRSi: $y^{0.333}$; bicarbonate: $y^{0.5}$; sulphate, nitrite, nitrate: $y^{0.25}$; ammonium, TP: $y^{0.111}$, chloride: $\left.\ln [y+1]\right)$ to obtain their normal distribution; furthermore, as well as the land use data, these distributions were also standardised (to a mean of 0 and a SD of 1) to make them comparable on the same scale. For the diatom abundance data, Hellinger transformation was applied.

The statistical analyses were carried out using $\mathrm{R}$ software (R Core Team, 2018) and R packages such as 'vegan' (Oksanen et al., 2018) and 'MASS' (Ripley et al., 2013) using stepAIC function were employed for multivariate analyses. For the calculation of functional richness 'FD' package (Laliberté \& Legendre, 2010) with the 'dbFD' function was applied.

\section{Results}

Land use forms and related environmental variables

In the PCA, the first two axes explained $47 \%$ of the variance in environmental variables and land use types. PC1 explained $35.5 \%$ of the total variance, and the main environmental factors correlated with this axis were: conductivity $(r=0.88)$, chloride $(r=0.84)$ bicarbonate $(r=0.84)$ and nitrite 
$(r=0.70)$. Among the land use forms, proportion (\%) of agricultural area displayed a strong positive correlation $(r=0.78)$ with this axis, while forest showed a strong negative correlation $(r=-0.80)$ PC2 explained $11.5 \%$ of the variance and correlated with the artificial $(r=-0.63)$ and water $(r=-0.46)$ surfaces as well as with $\mathrm{pH}(r=-0.63)$ (Fig. 3).

Effect of the environmental variables and the land use forms on diatoms

\section{Species-based redundancy analyses}

On the basis of the species composition along Axis 1 (explained variance: $7.1 \%$ ), it proved easy to distinguish the water basins characterized predominantly by agricultural areas and high bicarbonate and sulphate content from those are dominated mainly by forest (Fig. 4a). Along Axis 2 (explained variance: 5.8\%), the diatom community of the streams separated along the SRSi gradient (Fig. 4). The full RDA model containing 15 explanatory variables (environmental and land use) was significant $(p<0.001)$, but the explained variance by the first two axes was quite low (12.9\%). A higher proportion of agricultural area and higher nutrient and ion content were indicated by Navicula lanceolata Ehrenberg [NLAN],

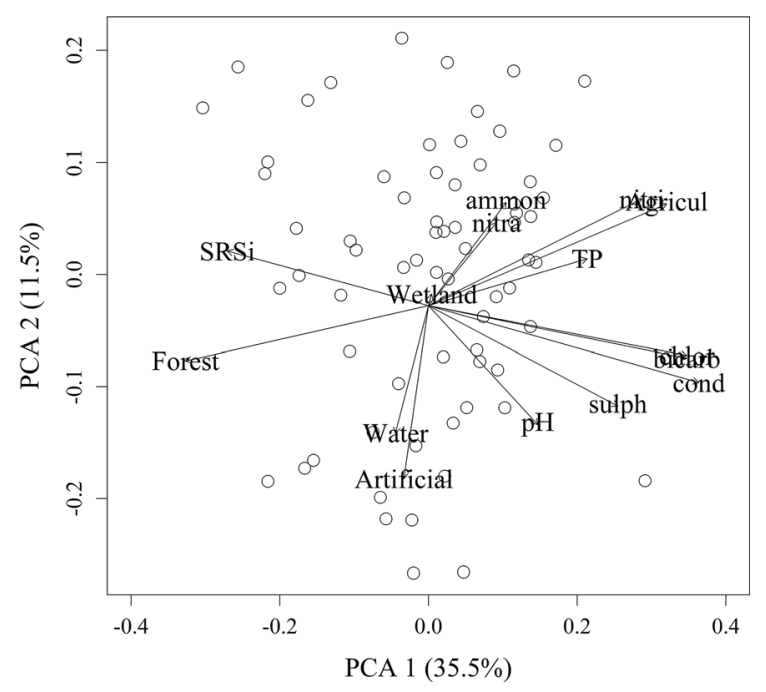

Fig. 3 PCA biplot based on the environmental and land use data of the studied streams (abbreviations: ammon ammonium, nitra nitrate, nitri nitrite, agricul agricultural, bicarb bicarbonate, chlor chloride, cond conductivity, sulph sulphate, SRSi soluble reactive silica)
Gomphonema olivaceum (Hornemann) Ehrenberg [GOLI], Planothidium lanceolatum (Brébisson ex Kützing) Lange-Bertalot [PTLA], Surirella brebissoni Krammer \& Lange-Bertalot [SBRE] and Nitzschia palea (Kützing) W.Smith [NPAL]. Gomphonema micropus Kützing [GMIC] and Meridion circulare (Greville) C.Agardh [MCIR] were unequivocal indicators of high nitrate concentration (Fig. 4a).

\section{Trait-based redundancy analyses}

Based on the trait composition, along Axis 1 (explained variance: $10.5 \%$ ), water basins dominated by agricultural land use could easily be distinguished from forest, wetland and water bodies land use types, whereas along Axis 2 (explained variance: 7.1\%), the sampling sites were arranged around the relatively high nitrate and SRSi content of the water (Fig. 4b). The full RDA model was significant $(p<0.001)$, but the explained variance along the two first axes was quite low (17.6\%). A high proportion of forest and wetland was indicated by low profile ecological guild (L) and smaller species (S1), or their combination (LS1). The LW3 trait was characteristic of increased nitrate concentration. The HLW2 trait was characteristic of high $\mathrm{pH}$, while nitrite and ammonium were primarily indicated by high and motile guilds, with middle-sized (HS3) and larger (HS4, MS4) species. Agricultural areas with elevated ion and TP concentrations were indicated by motile species with LW4 and S3 morphological traits. The LW1 trait was definitely characteristic of high SRSi content (Fig. 4b). Those species with a medium sized low profile (LS3) and small LW ratio (LLW2) could be found in areas dominated by water and artificial surfaces.

\section{Variation partitioning}

After the forward selection of the environmental variables, conductivity, $\mathrm{pH}$, bicarbonate, sulphate, nitrite, nitrate and SRSi were the most important constraints $(p<0.05)$ of the diatom species composition. Among the land use types only the proportion of the agricultural area had significant effect $(p<0.05)$ on the species composition. The variation partitioning revealed that the pure effect $(7.5 \%)$ of the selected environmental parameters was significant in contrast to the pure effect of land use $(0.6 \%)$. Their shared 


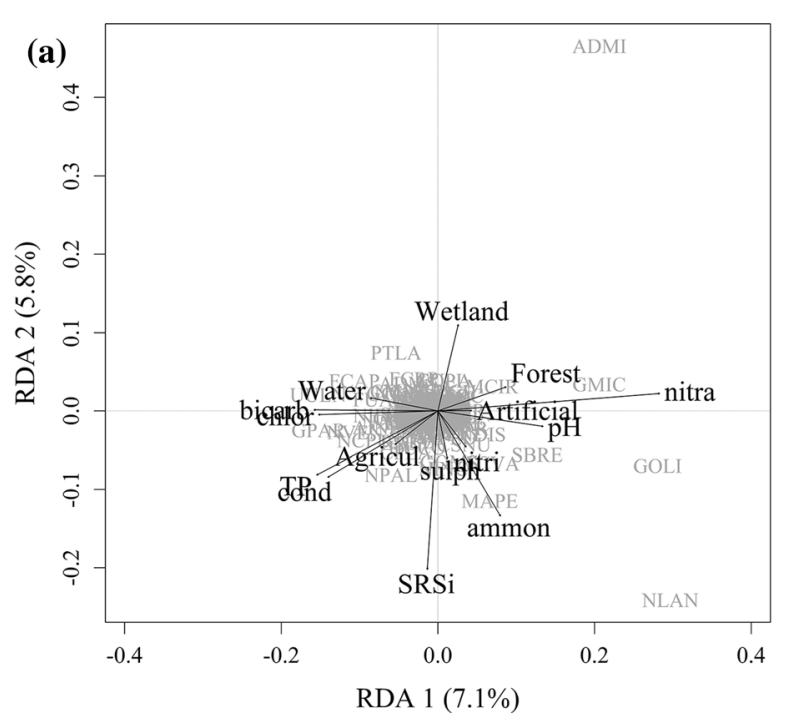

Fig. 4 a $\mathrm{RDA}_{1}$ : analysis of the diatom species composition, environmental and land use data; $\mathbf{b} \mathrm{RDA}_{2}$ : Analysis of the diatom trait composition, environmental and land use data

effect was low (1.2\%), one-sixth of the pure effect of the environmental variables (Fig. 5a).

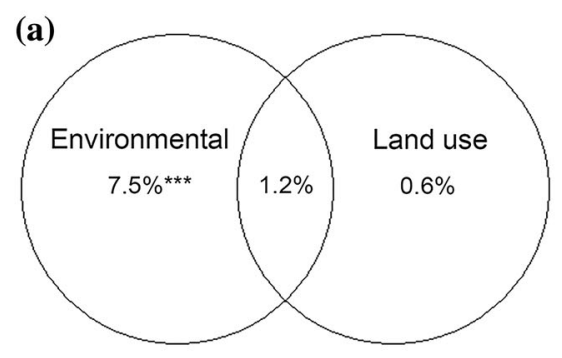

Residuals $=90.7 \%$

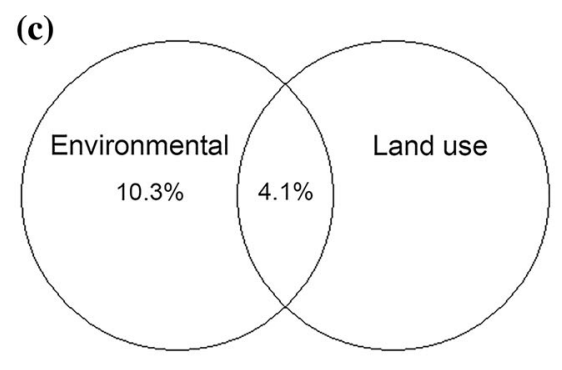

Residuals $=85.8 \%$

Fig. 5 Results of the variation partitioning conducted on a species abundance; b trait abundance $(* * * p<0.001)$; c species richness and $\mathbf{d}$ functional richness data. Proportions

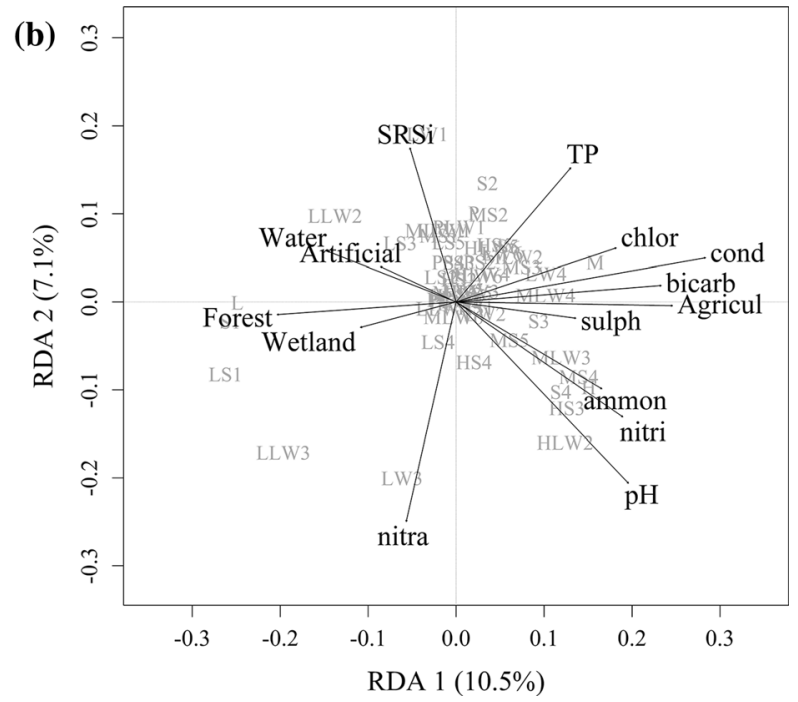

(abbreviations: ammon ammonium, nitra nitrate, nitri nitrite, agricul agricultural, bicarb bicarbonate, chlor chloride, cond conductivity, sulph sulphate, SRSi soluble reactive silica)

The results were similar in the case of the trait composition, which was mainly related to the pure effect $(7.8 \%)$ of the selected, significant

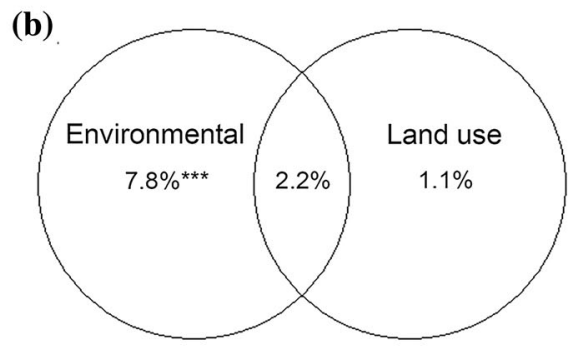

Residuals $=89.0 \%$

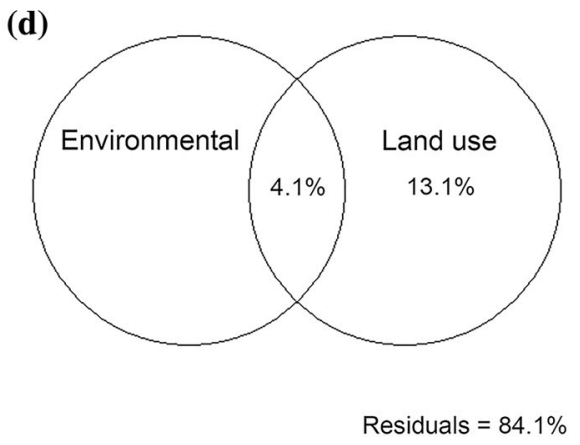

of the explained community variances are shown calculated from the adjusted $\mathrm{R}^{2}$ values. Residuals indicate the unexplained variance 
environmental variables such as conductivity, $\mathrm{pH}$, nitrite and SRSi. The pure effect of the land use, specifically the proportion (\%) of agricultural area which was the only significant land use type, was negligible in terms of explained variance, furthermore, their shared effect was also relatively low $(2.2 \%), \sim$ one-third of the pure effect of the environmental parameters (Fig. 5b).

Species richness was also primarily driven by the pure effect of the selected, significant environmental variables such as TP and ammonium (10.3\%), whereas the variance explained by the pure fraction of land use forms (proportion of the wetland and forest area) was $<0$. The shared fraction of the environmental variables and land use forms explained a lower proportion of variance $(4.1 \%)$ compared to the environmental variables alone (Fig. 5c).

In the case of the functional richness, variation partitioning revealed the relatively high $(13.1 \%)$ pure effect of the land use forms (proportion of the agricultural area and forest), and a lower proportion of explained variance $(4.1 \%)$ related to the shared effect of the environmental variables and land use forms (Fig. 5d).

Community and richness variation were only partly explained by the groups of selected variables and, consequently, the residuals were relatively high in each model presented here (Figs. 4, 5).

Relationship between land use types, traits and richness

For the selected traits defined by the RDA, the fitted LMs revealed that the relative extent of agricultural area (\%) had significant effect on the traits M, LW4 and S3 ( $r=0.32, p<0.01)$, and this relationship was stronger with the use of these traits and their combinations (M, LW4, S3, MLW4, MS3) $(r=0.38$, $p<0.001)$. The correlation of the extent of forest (\%) with the simple indicator traits (L, S1; $r=0.25$, $p<0.05)$ was slightly stronger than that of their combination (L, S1, LS1; $r=0.23, p<0.05$ ). The LM based on the proportion of water and artificial surfaces $(\%)$ and the LLW2 trait was also significant $(r=0.26$, $p<0.05$ ) (Table 2). On the basis of the fitted LMs, the $\%$ agricultural area had a significant positive effect ( $r=0.26, p<0.05)$ on the functional richness, while the $\%$ forest had a significant negative effect $(r=-0.35, p<0.01)$ both on the species and functional richness (Table 2).

Local effects of urbanisation

According to the NMDS analyses, the closeness of sampling sites to settlements (situated within the town, below the town at a distance of up to $1 \mathrm{~km}$ downstream, or far away from the urban area) did not significantly affect the community composition, even in the case of species abundance (ANOSIM $\mathrm{R}=0.044, p=0.16$; Fig. $6 \mathrm{a})$ or trait abundance (ANOSIM R $=0.048, p=0.14$; Fig. $6 b$ ) data. Kruskal-Wallis test also showed that species richness $(p=0.19)$ and functional richness $(p=0.14)$ did not differ between these sites (Fig. 7).

\section{Discussion}

General aspects

Catchment-level land use is basically determined by sociological and ecological interactions, which are, in turn, dependent on the level of economic development and technological advances, while climate and stochastic events (like floods and wildfires) also play a role (Hughes et al., 2016). In Hungary, the intensification of agricultural and industrial development and urbanisation date back to the middle of the twentieth century, and these subsequently caused significant deterioration in the ecological status of rivers (especially in the tributaries of the River Tisza) (Borics et al., 2016). In the streams studied here, the catchment-based approach of the WFD employed proved to be effective in the assessment of the key direct (environmental variables) and indirect (land use types) constraints on diatom community composition in these complex ecosystems. The most important variables (conductivity, $\mathrm{pH}, \mathrm{N}$ forms, $\mathrm{SRSi}, \%$ agriculture) in relation to diatom species and trait composition were similar. The species-based analyses highlighted the further importance of bicarbonate and sulphate concentration, but the explanatory power of the traitbased method was slightly higher, as registered in earlier studies (Abonyi et al., 2018; Stenger-Kovács et al., 2020). Besides effects of natural origin such as bedrock type (siliceous), land use also had significant impact on surface waters (Pacheco \& Fernandes, 
Table 2 Statistical parameters of the developed linear models between the diatom traits, species richness, functional richness and the land use types

\begin{tabular}{llrrrrr}
\hline Explanatory land use types & Response traits and functional diversity & Estimate & SE & $t$ & $r$ & $p$ \\
\hline Agriculture & M + LW4 + S3 & 0.034 & 0.011 & 2.97 & 0.32 & $<0.01$ \\
& M + LW4 + S3 + MLW4 + MS3 & 0.059 & 0.017 & 3.47 & 0.38 & $<0.001$ \\
& Functional richness & 0.001 & 0.000 & 2.43 & 0.26 & $<0.05$ \\
Forest & L + S1 & 0.037 & 0.016 & 2.30 & 0.25 & $<0.05$ \\
& L + S1 + LS1 & 0.053 & 0.024 & 2.18 & 0.23 & $<0.05$ \\
& Functional richness & -0.001 & 0.000 & -3.26 & -0.35 & $<0.01$ \\
& Species richness & -10.031 & 3.231 & -3.104 & -0.35 & $<0.01$ \\
Water + artifical surfaces & LLW2 & 0.042 & 0.018 & 2.38 & 0.26 & $<0.05$ \\
\hline
\end{tabular}
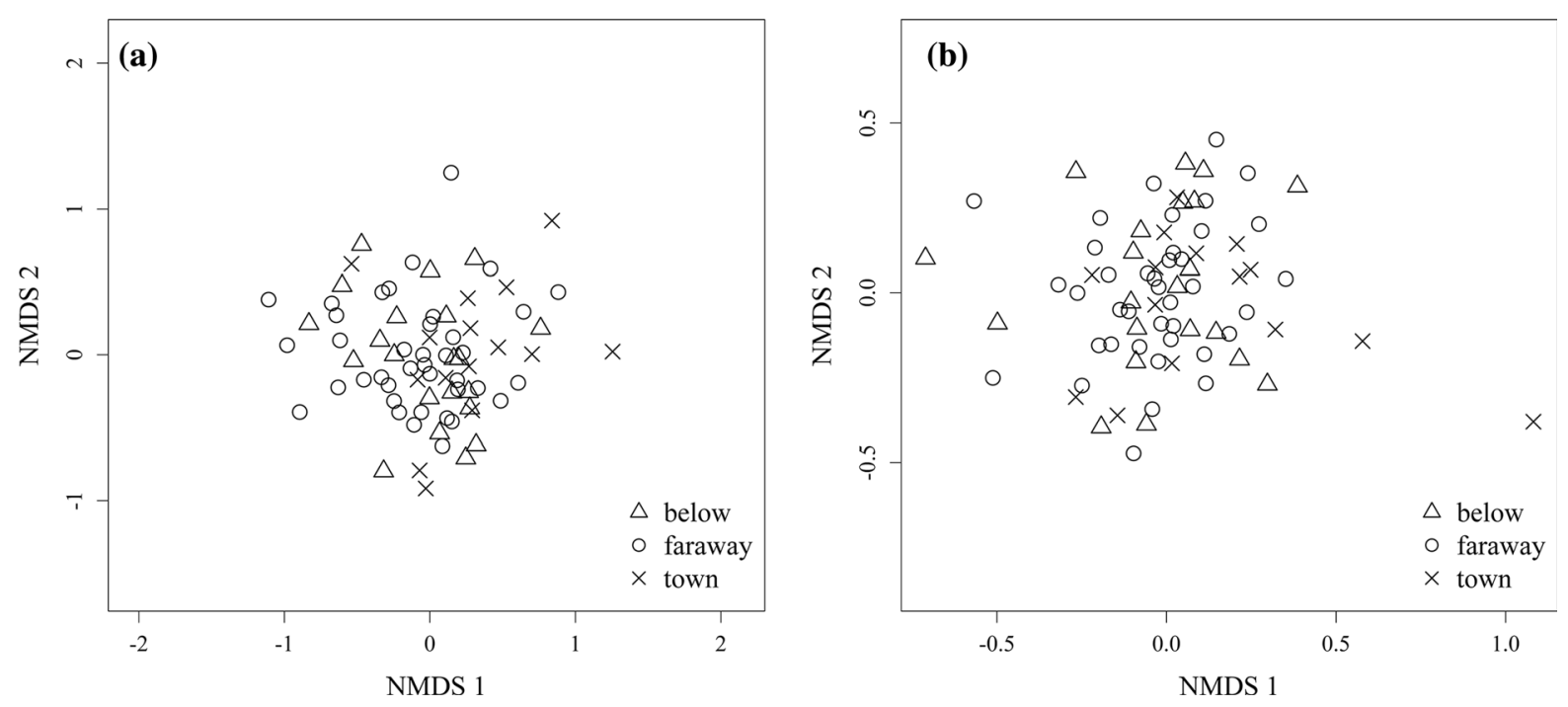

Fig. 6 NMDS analyses of benthic diatom samples based on the abundance data a of the diatom species (NMDS 1 : Bray-Curtis distance, stress 0.24$)$ and $\mathbf{b}$ of the diatom traits $\left(\mathrm{NMDS}_{2}\right.$ : Bray-Curtis distance, stress 0.21 )

2016) through the modification of water quality: in this study, a higher proportion of agricultural area, higher conductivity (due mainly to higher chloride and bicarbonate content) and nitrite concentration were characteristic, and an opposite trend was observed in the case of an increasing \% of forests, as observed in America in the $90 \mathrm{~s}$ (Leland, 1995), due to secondary salinization and fertilization. Diatom species and trait composition, as well as the species richness between catchments, varied primarily according to the local environmental variables, followed by the shared effects of the environmental factors and the land use types. This is in contrast to some previous findings for lentic phytoplankton communities (Qu et al., 2018) or boreal diatom stream communities (Teittinen et al., 2015), where their joint contribution to the explained variance of the communities was determinate. However, the differences in diatom species (Blinn \& Bailey, 2001, Teittinen et al., 2015) and trait composition (this study) between areas dominated by forests and agriculture are clear. Moreover, the variance of the functional richness was mostly explained by the pure effects of land use, as one of the consequences of human activity, and their ability to generate severe social conflicts (Valera et al., 2016).

In this study, the explanatory power of the models applied for diatom communities was obviously weak and a huge proportion of variances remained 

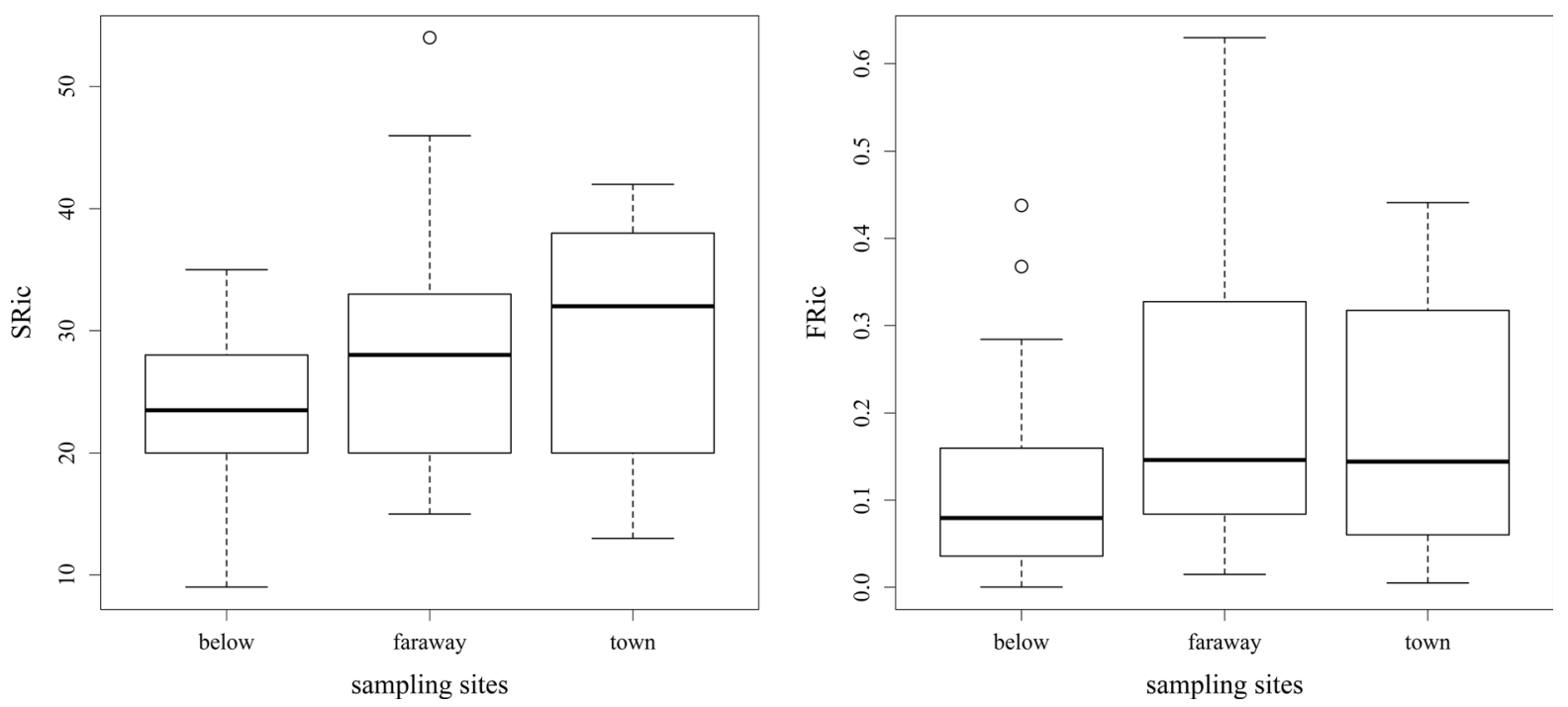

Fig. 7 Diatom species richness (SRich) and functional richness (FRich) in the town, below the town, up to $1 \mathrm{~km}$ downstream or far away $(>1 \mathrm{~km})$ from the urban area

unexplained, which is probably due to several other processes, such as unmeasured environmental variables that have important role in the establishment of communities (Leibold \& Chase, 2018). Further contributing factors might be the demographic stochasticity (when changes in birth and death rates can lead to the spatial and temporal drift in relative abundances of individuals) and the patch stochasticity (when the species has finite probability of colonizing unoccupied patches and going extinct in any time period). In addition, residual variance might consist of latent variance owing to correlations among species which can explain even $50 \%$ of the entire variance (Leibold $\&$ Chase, 2018). However, the proportion in variances of the species and functional richness explained by the studied variables were higher, revealing their stronger response to the environmental changes compared to the species- (Heino et al., 2010) or trait-based community structure.

Response of diatom functional traits

In natural, minimally disturbed watersheds dominated by forests, streams are primarily heterotrophic due to the shading provided by the extensive vegetation cover (Uieda \& Motta, 2007), which fundamentally protects the health of these ecosystems (Bunn et al., 1999). These healthy streams are characterised by low profile diatom ecological guilds and small cell size $\left(<100 \mu \mathrm{m}^{3}\right)$. Small species dominance with a simple community structure was also found in an experimental study of streams on afforested mountainsides (Cibils-Martina et al., 2017). Furthermore, low profile guild indicates low nutrient availability (Novais et al., 2014) due to its position in the benthic layer (Passy, 2007).

With the reduction of forested areas and extension of agricultural areas, the available light increases parallel to enhanced ion and nutrient content due to intensive irrigation and fertilization. Moreover, these agricultural activities in a catchment basin increase the turbidity and siltation in riverbeds (Bahls, 1993). These complex changes in such streams support the development of benthic layers dominated by the motile ecological guild and diatom species of middle size (300-600 $\mu^{3}$ ) and linear-lanceolate shape (like Navicula and Nitzschia species). That is, higher light intensity favours the larger species, which have a competitive advantage in this environment (Lange et al., 2011). Higher turbidity and siltation, however, limit high light intensity; therefore, middle size and linear-lanceolate outlines are characteristic. The effect of agriculture in modifying body size can also be observed among benthic insects (Krynak \& Yates, 2020), even though its mechanism has not been explored. Furthermore, this shape also serves as a light trap, making the capture of the required amount of sunshine possible (Stenger-Kovács et al., 2018), as 
well as the motility of the species in the selection of the most suitable habitats (Passy, 2007) in turbid, nutrient rich environments (Tapolczai et al., 2017, Soininen et al., 2016). This environmental filtering supports the homogenizing effect of agriculture, which has been highlighted in the case of strongly alkaline rivers (Pillsbury et al., 2019).

Low profile guild with LW2 length-width ratio indicates the increased $\%$ of water and artificial surfaces. Besides, the dominance of low profile guild occurs primarily in nutrient reduced environments (Stevenson et al., 2006), as the higher proportion of water surface enables the increased spread of algal species. Artificial (impermeable) surface areas may further support this process by accelerating the runoff (Sterling et al., 2012), as well as the reaching of the local erosion base in very short time, which may, in turn, open a new route for the spread of invasive species. This primarily favours the diatom species Amphora, Planothidium, Achnnanthidium, Reimeria and Halamphora, whose shape and type of attachment to the substratum enable their colonization in already established benthic layers: diatom cells with a slightly elongated outline attach apically, parallel or vertical to the substratum. This strong attachment provides them with a measure of resistance to high discharge (shear stress) (Tapolczai et al., 2017).

Response of species and functional richness

Diatom functional richness increases in the agriculture-dominated water basin similar to functional richness of macroinvertebrates (Moore \& Palmer, 2005) and both the species and functional richness decrease with an increasing $\%$ of forests. In degraded ecosystems, where a high proportion of agricultural area is characteristic, higher nutrient concentration can be responsible (Wang et al., 1997) for this increment of functional richness. However, in forested areas, forests can keep back the water, alluvium and nutrients, and consequently, an upstream diatom community with reduced diversity can be established (Blinn \& Bailey, 2001) in a controlled environment characterised by shading and a stable water regime. An increasingly agricultural setting will also result in a considerably decrease in the species richness of fish, due to the presence of homogenised and proliferate macrovegetation in the stream bed (Tóth et al., 2019).
Local and catchment scale effects of urbanisation

On the catchment scale, the reduced RDA models showed no significant effects owing to urbanisation (quantified as a \% artificial area) in either the case of diatom species or trait composition. This may be due to the relatively low intensity of urbanisation (average: $1.5 \%)$ compared to the agricultural area (average: $55.3 \%$ ) in the studied catchments, which was probably not enough to lead to the homogenisation of the urban communities, which has been described worldwide (e.g. McKinney, 2006). Any direct, local environmental filtering effect of urbanisation was also negligible: it did not modify either species or trait composition. Benthic diatoms may be less sensitive to artificial surfaces (e.g. concrete in channelled streams), which can provide a neutral surface similar to a natural one, such as stones. This stands in contrast to the case of macroinvertebrates (Barnum et al., 2017), whose trophic structure can be modified by a channelled/natural stream bed through the provision of detritus of different sizes (Docile et al., 2016). Diatom species and functional richness did not respond to this local anthropogenic effect, likewise the degree of species richness found in a study of Australian streams, which varied inconsistently along the urbanisation gradient, indicating rather a situation of nutrient enrichment (Sonneman et al., 2001).

\section{Conclusion}

Agriculture and urbanisation need to be regarded as the most serious kinds of habitat alteration, affecting freshwater ecosystems and functions to a considerable extent. In Hungary, in the case of low order streams at low altitudes, the effect of agriculture is more pronounced than the effect of urbanisation at this lower level, even on the local scale, as also on the catchment scale. However, with the further spread of urbanisation, the increasing significance of its influence may be predicted. Moreover, besides these anthropogenic land modifications, climate change will further threaten the good ecological status of such environments. Therefore, the preservation of the characteristic trait assemblages and richness of natural, undisturbed ecosystems is fundamental to the conservation science and our future. 
Acknowledgements Open access funding provided by University of Pannonia (PE). We would like to thank János Korponai for his help with the statistics, while Attila J. Trájer assisted with the GIS analyses. We are also very grateful to the current and former colleagues and students of the Department of Limnology for field sampling and laboratory analyses of water chemical variables. Special thanks to Paul Thatcher and Luciane O. Crossetti for proofreading. The study was financed by the National Research Development and Innovation Office (NKFIH K120595), as well as by the Széchenyi 2020 grant under the EFOP-3.6.1-16-2016-00015 and the European Regional Development Fund (GINOP-2.3.2-15-2016-00019). Csilla Stenger-Kovács was supported by the Higher Educational Institutional Excellence Program 2019 (NKFIH-1158-6/2019).

Open Access This article is licensed under a Creative Commons Attribution 4.0 International License, which permits use, sharing, adaptation, distribution and reproduction in any medium or format, as long as you give appropriate credit to the original author(s) and the source, provide a link to the Creative Commons licence, and indicate if changes were made. The images or other third party material in this article are included in the article's Creative Commons licence, unless indicated otherwise in a credit line to the material. If material is not included in the article's Creative Commons licence and your intended use is not permitted by statutory regulation or exceeds the permitted use, you will need to obtain permission directly from the copyright holder. To view a copy of this licence, visit http://creativecommons.org/licenses/by/4.0/.

\section{References}

[APHA] American Public Health Association, 1998. Standard Methods for the Examination of Water and Wastewater. United Book Press, Baltimore.

Abonyi, A., É. Ács, A. Hidas, I. Grigorszky, G. Várbíró, G. Borics \& K. T. Kiss, 2018. Functional diversity of phytoplankton highlights long term gradual regime shift in the middle section of the Danube River due to global warming, human impacts and oligotrophication. Freshwater Biology 63: 456-472.

Allan, J. D., 2004. Landscapes and riverscapes: the influence of land use on stream ecosystems. Annual Review of Ecology and Systematics 35: 257-284.

Bahls, L. L., 1993. Periphyton Bioassessment Methods for Montana Streams. Water Quality Bureau, Department of Health and Environmental Sciences, Helena.

Barnosky, A. D., N. Matzke, S. Tomiya, G. O. Wogan, B. Swartz, T. B. Quental \& B. Mersey, 2011. Has the Earth's sixth mass extinction already arrived? Nature 471: 51.

Barnum, T. R., D. E. Weller \& M. Williams, 2017. Urbanization reduces and homogenizes trait diversity in stream macroinvertebrate communities. Ecological Applications 27: 2428-2442.

Bellinger, B. J., C. Cocquyt \& C. M. O’Reilly, 2006. Benthic diatoms as indicators of eutrophication in tropical streams. Hydrobiologia 573: 75-87.
Béres, B., V. Á. Lukács, P. Török, Z. Kókai, Z. Novák, E. T. Krasznai \& I. Bácsi, 2016. Combined eco-morphological functional groups are reliable indicators of colonisation processes of benthic diatom assemblages in a lowland stream. Ecological Indicators 64: 31-38.

Berthon, V., A. Bouchez \& F. Rimet, 2011. Using diatom lifeforms and ecological guilds to assess organic pollution and trophic level in rivers: a case study of rivers in south eastern France. Hydrobiologia 673: 259-271.

Blinn, D. W. \& P. C. Bailey, 2001. Land-use influence on stream water quality and diatom communities in Victoria, Australia: a response to secondary salinization. Hydrobiologia 466: 231-244.

Borcard, D., P. Legendre \& P. Drapeau, 1992. Partialling out the spatial component of ecological variation. Ecology 73 : 1045-1055.

Borics, G., É. Ács, P. Boda, E. Boros, T. Erős, I. Grigorszky, K. T. Kiss, Sz Lengyel, N. M. Reskóné, B. Somogyi \& L. Vörös, 2016. Water bodies in Hungary-an overview of their management and present state. Hungarian Journal of Hydrology 96: 57-67.

Bunn, S. E., P. M. Davies \& T. D. Mosisch, 1999. Ecosystem measures of river health and their response to riparian and catchment degradation. Freshwater Biology 41: 333-345.

Butchart, S. H., M. Walpole, B. Collen, A. Van Strien, J. P. Scharlemann, R. E. Almond \& K. E. Carpenter, 2010. Global biodiversity: indicators of recent declines. Science 328: 1164-1168.

CEN (Comité Européen de Normalisation), 2003. Water Quality Guidance Standard for the Routine Sampling and Pretreatment of Benthic Diatoms from Rivers. EN 13946:2003. CEN, Geneva.

Cibils-Martina, L., R. E. Principe, J. A. Márquez, E. N. Gari \& R. J. Albariño, 2017. Succession of algal communities in headwaters: a comparison of pine afforested and natural grassland streams. Ecological Research 32: 423-434.

Copernicus, 2020. The current Corine Land Cover 2006 version is v.20: https://land.copernicus.eu/pan-european/corineland-cover/clc-2006?tab=download.

Dahm, V., D. Hering, D. Nemitz, W. Graf, A. Schmidt-Kloiber, P. Leitner \& C. K. Feld, 2013. Effects of physico-chemistry, land use and hydromorphology on three riverine organism groups: a comparative analysis with monitoring data from Germany and Austria. Hydrobiologia 704: 389-415.

Dela-Cruz, J., T. I. M. Pritchard, G. Gordon \& P. Ajani, 2006. The use of periphytic diatoms as a means of assessing impacts of point source inorganic nutrient pollution in south-eastern Australia. Freshwater Biology 51: 951-972.

Docile, T., D. C. Rosa, R. Figueiró \& J. Nessimian, 2016. Urbanisation alters the flow of energy through stream food webs. Insect Conservation and Diversity 9: 416-426.

Dolédec, S. \& B. Statzner, 2008. Invertebrate traits for the biomonitoring of large European rivers: an assessment of specific types of human impact. Freshwater Biology 53: 617-634.

Dudgeon, D., A. H. Arthington, M. O. Gessner, Z.-I. Kawabata, D. J. Knowler, C. Léveque, R. J. Naiman, A.-H. PrieurRichard, D. Soto, M. L. J. Stiassny \& C. A. Sullivan, 2006. Freshwater biodiversity: importance, threats, status and conservation challenges. Biological Revivew 81: 163-182. 
Flynn, D. F., N. Mirotchnick, M. Jain, M. I. Palmer \& S. Naeem, 2011. Functional and phylogenetic diversity as predictors of biodiversity-ecosystem function relationships. Ecology 92: 1573-1581.

Grimm, N. B., S. H. Faeth, N. E. Golubiewski, C. L. Redman, J. Wu, X. Bai \& J. M. Briggs, 2008. Global change and the ecology of cities. Science 319: 756-760.

Guiry, M. D., \& G. M. Guiry, 2019. AlgaeBase. World-wide Electronic Publication, National University of Ireland, Galway. http://www.algaebase.org. Accessed 24 Nov 2019.

Heino, J., L. M. Bini, S. M. Karjalainen, H. Mykrä, J. Soininen, L. C. G. Vieira \& J. A. F. Diniz-Filho, 2010. Geographical patterns of micro-organismal community structure: are diatoms ubiquitously distributed across boreal streams? Oikos 119: 129-137.

Hering, D., R. K. Johnson, S. Kramm, S. Schmutz, K. Szoszkiewicz \& P. F. Verdonschot, 2006. Assessment of European streams with diatoms, macrophytes, macroinvertebrates and fish: a comparative metric-based analysis of organism response to stress. Freshwater Biology 51: 1757-1785.

Hoorman, J., T. Hone, T. Sudman Jr., T. Dirksen, J. Iles \& K. Islam, 2008. Agricultural impacts on lake and stream water quality in Grand Lake St. Marys, Western Ohio. Water: Air, and Soil Pollution 193: 309-322.

Hughes, S. J., J. A. Cabral, R. Bastos, R. Cortes, J. Vicente, D. Eitelberg \& M. Santos, 2016. A stochastic dynamic model to assess land use change scenarios on the ecological status of fluvial water bodies under the Water Framework Directive. Science of the Total Environment 565: 427-439.

Jonsson, M., R. M. Burrows, J. Lidman, E. Fältström, H. Laudon \& R. A. Sponseller, 2017. Land use influences macroinvertebrate community composition in boreal headwaters through altered stream conditions. Ambio 46: 311-323.

Krynak, E. M. \& A. G. Yates, 2020. Intensive agriculture alters the biomass size spectrum and body-mass of benthic insects: evidence from a reciprocal transfer experiment. Hydrobiologia 847: 1221-1235.

Laliberté, E. \& P. Legendre, 2010. A distance-based framework for measuring functional diversity from multiple traits. Ecology 91: 299-305.

Lange, K., A. Liess, J. J. Piggott, C. R. Townsend \& C. D. Matthaei, 2011. Light, nutrients and grazing interact to determine stream diatom community composition and functional group structure. Freshwater Biology 56: 264-278.

Leibold, M. A. \& J. M. Chase, 2018. Metacommunity Ecology. Princeton University Press, Princeton.

Leland, H. V., 1995. Distribution of phytobenthos in the Yakima River basin, Washington, in relation to geology, land use and other environmental factors. Canadian Journal of Fisheries and Aquatic Sciences 52: 1108-1129.

Li, B., W. Tan, L. Wen, X. Zhao, B. Peng, J. Yang \& G. Lei, 2020. Anthropogenic habitat alternation significantly decreases $\alpha$-and $\beta$-diversity of benthopelagic metacommunity in a large floodplain lake. Hydrobiologia 847: 293-307.

Mangadze, T., T. Bere \& T. Mwedzi, 2016. Choice of biota in stream assessment and monitoring programs in tropical streams: a comparison of diatoms, macroinvertebrates and fish. Ecological Indicators 63: 128-143.

McKinney, M. L., 2006. Urbanization as a major cause of biotic homogenization. Biological Conservation 127: 247-260.

Moore, A. A. \& M. A. Palmer, 2005. Invertebrate biodiversity in agricultural and urban headwater streams: implications for conservation and management. Ecological Applications 15: 1169-1177.

Newall, P. \& C. J. Walsh, 2005. Response of epilithic diatom assemblages to urbanization influences. Hydrobiologia 532: 53-67.

Novais, M. H., M. M. Morais, J. Rosado, L. S. Dlas, H. Hoffmann \& L. Ector, 2014. Diatoms of temporary and permanent watercourses in Southern Europe (Portugal). River Research and Applications 30: 1216-1232.

Oeding, S., K. H. Taffs, B. Cox, A. Reichelt-Brushett \& C. Sullivan, 2018. The influence of land use in a highly modified catchment: investigating the importance of scale in riverine health assessment. Journal of Environmental Management 206: 1007-1019.

Oksanen, J., F. Guillaume Blanchet, M. Friendlym, R. Kindt, P. Legendre, D. McGlinn, et al., 2018. vegan: Community ecology package. R package version 2.5-2. https://CRAN. R-project.org/package=vegan.

Pacheco, F. A. L. \& L. S. Fernandes, 2016. Environmental land use conflicts in catchments: a major cause of amplified nitrate in river water. Science of the Total Environment 548: 173-188.

Pan, Y., A. Herlihy, P. Kaufmann, J. Wigington, J. Van Sickle \& T. Moser, 2004. Linkages among land-use, water quality, physical habitat conditions and lotic diatom assemblages: a multi-spatial scale assessment. Hydrobiologia 515: 59-73.

Passy, S. I., 2007. Diatom ecological guilds display distinct and predictable behaviour along nutrient and disturbance gradients in running waters. Aquatic Botany 86: 171-178.

Pillsbury, R., R. J. Stevenson, M. D. Munn \& I. Waite, 2019. Relationships between diatom metrics based on species nutrient traits and agricultural land use. Environmental Monitoring and Assessment 191: 228.

Qu, Y., N. Wu, K. Makarevičiūtè, B. Guse \& N. Fohrer, 2018. Effects of land-use pattern and physiochemical conditions on phytoplankton communities in a German lowland catchment. Fundamental and Applied Limnology/Archiv für Hydrobiologie 191: 175-187.

R Core Team, 2018. R: A Language and Environment for Statistical Computing. R Foundation for Statistical Computing, Vienna.

Reynolds, C. S., V. Huszar, C. Kruk, L. Naselli-Flores \& S. Melo, 2002. Towards a functional classification of the freshwater phytoplankton. Journal of Plankton Research 24: 417-428.

Richards, C., L. B. Johnson \& G. E. Host, 1996. Landscapescale influences on stream habitats and biota. Canadian Journal of Fisheries and Aquatic Sciences 53: 295-311.

Rimet, F. \& A. Bouchez, 2012. Life-forms, cell-sizes and ecological guilds of diatoms in European rivers. Knowledge and Management of Aquatic Ecosystems 406: 501.

Ripley, B., B. Venables, D. M. Bates, K. Hornik, A. Gebhardt, D. Firth \& M. B. Ripley, 2013. Package 'mass'. Cran R, 538. 
Seto, K. C., M. Fragkias, B. Güneralp, M. K. Reilly \& A. Pidgeon, 2011. A meta-analysis of global urban land expansion. PLoS ONE 6: e23777.

Soininen, J., A. Jamoneau, J. Rosebery \& S. I. Passy, 2016. Global patterns and drivers of species and trait composition in diatoms. Global Ecology and Biogeography 25: 940-950.

Sonneman, J. A., C. J. Walsh, P. F. Breen \& A. K. Sharpe, 2001. Effects of urbanization on streams of the Melbourne region, Victoria, Australia. II. Benthic diatom communities. Freshwater Biology 46: 553-565.

Sponseller, R. A., E. F. Benfield \& H. M. Valett, 2001. Relationships between land use, spatial scale and stream macroinvertebrate communities. Freshwater Biology 46: 1409-1424.

Stenger-Kovács, C., L. Tóth, F. Tóth, E. Hajnal \& J. Padisák, 2014. Stream order-dependent diversity metrics of epilithic diatom assemblages. Hydrobiologia 721: 67-75.

Stenger-Kovács, C., K. Körmendi, E. Lengyel, A. Abonyi, É. Hajnal, B. Szabó \& J. Padisák, 2018. Expanding the traitbased concept of benthic diatoms: development of trait-and species-based indices for conductivity as the master variable of ecological status in continental saline lakes. Ecological Indicators 95: 63-74.

Stenger-Kovács, C., E. Lengyel, K. Buczkó, J. Padisák \& J. Korponai, 2020. Trait-based diatom functional diversity as an appropriate tool for understanding the effects of environmental changes in soda pans. Ecology and Evolution. https://doi.org/10.1002/ece3.5897.

Sterling, S. M., A. Ducharne \& J. Polcher, 2012. The impact of global land-cover change on the terrestrial water cycle. Nature Climate Change 3: 385-390.

Stevenson, R. J., M. L. Bothwell \& R. L. Lowe (eds), 1996. Algal Ecology: Freshwater Benthic Ecosystems. Academic Press, San Diego.

Stevenson, R. J., S. T. Rier, C. M. Riseng, R. E. Schultz \& M. J. Wiley, 2006. Comparing effects of nutrients on algal biomass in streams in two regions with different disturbance regimes and with applications for developing nutrient criteria. Hydrobiology 561: 149-165.

Stoate, C., N. Boatman, R. Borralho, C. R. Carvalho, G. De Snoo \& P. Eden, 2001. Ecological impacts of arable intensification in Europe. Journal of Environmental Management 63: 337-365.

Tapolczai, K., A. Bouchez, C. Stenger-Kovács, J. Padisák \& F. Rimet, 2017. Taxonomy- or trait-based ecological assessment for tropical rivers? Case study on benthic diatoms in Mayotte island (France, Indian Ocean). Science of the Total Environment 607-608: 1293-1303.
Teittinen, A., M. Taka, O. Ruth \& J. Soininen, 2015. Variation in stream diatom communities in relation to water quality and catchment variables in a boreal, urbanized region. Science of the Total Environment 530-531: 279-289.

Tolkkinen, M. J., H. Mykrä, R. Virtanen, M. Tolkkinen, T. Kauppila, L. Paasivirta \& T. Muotka, 2016. Land use impacts on stream community composition and concordance along a natural stress gradient. Ecological Indicators 62: 14-21.

Tóth, R., I. Czeglédi, B. Kern \& T. Erős, 2019. Land use effects in riverscapes: diversity and environmental drivers of stream fish communities in protected, agricultural and urban landscapes. Ecological Indicators 101: 742-748.

Uieda, V. S. \& R. L. Motta, 2007. Trophic organization and food web structure of south-eastern Brazilian streams: a review. Acta Limnologica Brasiliensia 19: 15-30.

Valera, C. A., R. V. Junior, S. G. P. Varandas, L. S. Fernandes \& F. A. L. Pacheco, 2016. The role of environmental land use conflicts in soil fertility: a study on the Uberaba River basin, Brazil. Science of the Total Environment 562: 463-473.

Villéger, S., N. W. Mason \& D. Mouillot, 2008. New multidimensional functional diversity indices for a multifaceted framework in functional ecology. Ecology 89: 2290-2301.

Vörösmarty, C. J., P. B. McIntyre, M. O. Gessner, D. Dudgeon, A. Prusevich, P. Green, S. Glidden, S. E. Bunn, C. A. Sullivan, C. R. Liermann \& P. M. Davies, 2010. Global threats to human water security and river biodiversity. Nature 467 : $555-561$.

Wallace, J. B. \& J. R. Webster, 1996. The role of macroinvertebrates in stream ecosystem function. Annual Review of Entomology 41: 115-139.

Walsh, G. W. \& V. Wepener, 2009. The influence of land use on water quality and diatom community structures in urban and agriculturally stressed rivers. Water SA 35: 579-594.

Walsh, C. J., P. J. Papas, D. Crowther \& J. Yoo, 2004. Stormwater drainage pipes as a threat to a stream-dwelling amphipod of conservation significance, Austrogammarus australis in southeastern Australia. Biodiversity Conservation 13: 781-793.

Wang, L., J. Lyons, P. Kanehl \& R. Gatti, 1997. Influences of watershed land use on habitat quality and biotic integrity in Wisconsin streams. Fisheries 22: 6-12.

Wetzel, R. G. \& G. E. Likens, 2000. Limnological Analyses. Springer, New York.

Publisher's Note Springer Nature remains neutral with regard to jurisdictional claims in published maps and institutional affiliations. 